\title{
The contribution of hyperglycaemia and hypoinsulinaemia to the insulin resistance of streptozotocin-diabetic rats
}

\author{
G. Lisato $^{1}$, I. Cusin ${ }^{2}$, A. Tiengo ${ }^{1}$, S.Del Prato ${ }^{1}$ and B. Jeanrenaud ${ }^{2}$ \\ ${ }^{1}$ Cattedra di Malattie del Ricambio, Università di Padova, Italy, and ${ }^{2}$ Laboratories de Recherche Metaboliques, Geneva, Switzerland
}

\begin{abstract}
Summary. The relative contribution of hyperglycaemia and hypoinsulinaemia was evaluated in rats made diabetic by streptozotocin administration. Four groups of rats were studied: untreated normal rats; streptozotocin-diabetic; streptozotocin-diabetic treated with phlorizin $(0.4 \mathrm{mg} / \mathrm{kg}$ body weight per day); streptozotocin-diabetic mildly treated with insulin (0.7 IU/day). In all groups, insulin action (responsiveness) was assessed with the euglycaemic $(5.3 \mathrm{mmol} / \mathrm{l})$ hyperinsulinaemic $(524 \mathrm{mU} / \mathrm{l})$ clamp technique combined with ${ }^{3} \mathrm{H}-2$-deoxy-D-glucose method, enabling determination of the glucose utilization index in various tissues. Responsiveness of the overall glucose utilization process to insulin was reduced by $28 \%$ in streptozotocin-diabetic rats $(12.0 \pm 1.2$ vs $\left.16.5 \pm 0.6 \mathrm{mg} \cdot \mathrm{kg}^{-1} \cdot \mathrm{min}^{-1}, p<0.001\right)$. This was associated with a significant reduction $(p<0.05)$ in the glucose utilization index in all muscles studied (average $=17.0$ vs $32.1 \mathrm{ng} \cdot \mathrm{mg}$ of tissue $\left.^{-1} \cdot \mathrm{min}^{-1}\right)$, in the heart (19.6 vs $\left.39.5 \mathrm{ng} \cdot \mathrm{mg}^{-1} \cdot \mathrm{min}^{-1}\right)$, brown adipose tissue (98.9 vs $\left.178.0 \mathrm{ng} \cdot \mathrm{mg}^{-1} \cdot \mathrm{min}^{-1}\right)$, skin (6.4 vs $13.1 \mathrm{ng} \cdot \mathrm{mg}^{-1} \cdot \mathrm{min}^{-1}$ ). Phlorizin treatment normalized plasma glucose levels with-
\end{abstract}

out affecting those of insulin, and restored overall glucose utilization to normal $\left(16.6 \pm 1.0 \mathrm{mg} \cdot \mathrm{kg}^{-1} \cdot \mathrm{min}^{-1}\right)$. This normalization was accompanied by a normalization of the glucose utilization index in all muscle types studied $\left(29.2 \mathrm{ng} \cdot \mathrm{mg}^{-1} \cdot \mathrm{min}^{-1}\right)$, in the heart $\left(50.0 \mathrm{ng} \cdot \mathrm{mg}^{-1} \cdot \mathrm{min}^{-1}\right)$, brown adipose tissue $\left(157.2 \mathrm{ng} \cdot \mathrm{mg}^{-1} \cdot \mathrm{min}^{-1}\right)$, and skin $\left(10.0 \mathrm{ng} \cdot \mathrm{mg}^{-1} \cdot \mathrm{min}^{-1}\right)$. White adipose tissue, brain and gut were not affected. Mild insulin treatment with persistent hyperglycaemia was not able to significantly ameliorate glucose disposal $\left(14.5 \pm 0.9 \mathrm{mg} \cdot \mathrm{kg}^{-1} \cdot \mathrm{min}^{-1}\right)$ or the glucose utilization index of most individual tissues (muscle $=18.4$; heart $=36.2$; brown adipose tissue $=148.0$; skin $=7.7 \mathrm{ng}$. $\left.\mathrm{mg}^{-1} \cdot \mathrm{min}^{-1}\right)$. These data show that correction of hyperglycaemia in streptozotocin-diabetic rats normalizes insulin action, while partial correction of the hypoinsulinaemia fails to do so.

Key words: Streptozotocin diabetes, hyperglycaemia, phlorizin, insulin treatment, glucose utilization index, 2-deoxy-D-glucose.
Insulin resistance is a characteristic feature of diabetes mellitus. Nevertheless, it is not clear whether such resistance is inherent to the diabetic condition, or whether it is related to the hormonal and metabolic alterations of the diabetic state.

The presence of insulin resistance in relatives of patients with Type 2 (non-insulin-dependent) diabetes who have normal glucose tolerance [1] supports the hypothesis of an inherited defect in insulin action. On the other hand, the observation that hypoinsulinaemia in diabetic rats $[2$, $3]$ and dogs $[4,5]$ is followed by a state of insulin resistance which can be improved by restoration of adequate levels of circulating insulin, emphasizes the importance of the metabolic-hormonal homeostasis. Insulin deficiency, associated with hyperglycaemia and chronic elevation of plasma glucose concentrations, alters the insulin sensitivity of peripheral tissues. Following an initial proposal made by Unger and Grundy [6], evidence has become available which supports their hypothesis that hyperglycaemia may have a deleterious effect on the target tissues of insulin $[7,8]$. Thus, the reduction in plasma glucose level by e. g. diet, oral hypoglycaemic agents, insulin is expected to improve insulin action. Correction of hyperglycaemia by phlorizin in diabetic rats has been shown to restore the insulin-mediated overall glucose disposal to normal, without affecting either fasting or glucose-stimulated insulin levels [7].

The present study attempts to define in various tissues of streptozotocin (STZ)-induced diabetic rats the relative contribution of insulin deficiency compared to that of hyperglycaemia. For this purpose we have examined the changes in insulin responsiveness in STZ-diabetic rats before, and after phlorizin or mild insulin treatment, by using the euglycaemic hyperinsulinaemic clamp tech- 
Table 1. Fasting and fed basal glycaemia and insulinaemia in normal, diabetic, diabetic phlorizin-treated, and diabetic insulin-treated rats

\begin{tabular}{|c|c|c|c|c|c|c|}
\hline \multirow{2}{*}{\multicolumn{2}{|c|}{ Group }} & \multirow[b]{2}{*}{$\begin{array}{l}\text { Number of } \\
\text { experiments }\end{array}$} & \multicolumn{2}{|c|}{ Glycaemia } & \multicolumn{2}{|c|}{ Insulinaemia } \\
\hline & & & $\begin{array}{l}\text { Fasting } \\
(\mathrm{mmol} / \mathrm{l})\end{array}$ & Fed & $\begin{array}{l}\text { Fasting } \\
(\mathrm{mU} / \mathrm{l})\end{array}$ & Fed \\
\hline II & Diabetic & 6 & $6.0 \pm 0.2$ & $28.3 \pm 1.1$ & $28 \pm 5$ & $30 \pm 2$ \\
\hline III & Diabetic plus phlorizin & 6 & $4.6 \pm 0.1$ & $8.3 \pm 0.4$ & $25 \pm 4$ & $30 \pm 3$ \\
\hline IV & Diabetic plus insulin & 5 & $5.4 \pm 0.6$ & $14.9 \pm 2.8$ & $60 \pm 8$ & $65 \pm 3$ \\
\hline
\end{tabular}

Diabetes was produced by streptozotocin (STZ) administration to normal rats; insulin treatment refers to a mild treatment of the STZdiabetic rats with insulin.

Fasting glycaemia: I vs II, $p<0.05 ;$ I vs III and IV, NS; Fed glycaemia:

nique. The latter was combined with the labelled 2-deoxyD-glucose technique to assess the changes in the glucose utilization index of individual tissues.

\section{Materials and methods}

\section{Experimental protocol}

Four groups of normal male rats of the Zucker (FA/FA) strain were used. They were 10-11 weeks old and weighed $200-250 \mathrm{~g}$. Group I consisted of control rats $(n=6)$; Group II, of STZ-diabetic rats $(n=6)$; Group III, of STZ-diabetic rats treated with phlorizin $(n=6)$, and Group IV, of STZ-diabetic rats treated with insulin $(n=5)$.

In Group II, III and IV, non-ketotic diabetes was produced by intracardiac injection of $35 \mathrm{mg} / \mathrm{kg}$ body weight of STZ. Control animals (Group I) received an intracardiac isotonic $0.9 \% \mathrm{NaCl}$ injection. Following these procedures, all animals were housed in individual cages and placed in an animal quarter with a fixed darklight (18.00 to 06.00 hours) cycle. The rats received an identical daily allotment of a standard laboratory chow $(0.1 \mathrm{~g} / \mathrm{g}$ body weight per day) $[7,9]$ that was completely consumed by all the animals thereby allowing for their normal growth.

After STZ injection, the rats were weighed twice weekly and tail vein blood collected daily for the determination of fed plasma glucose levels. After 7 days of overt hyperglycaemia (>10 mmol/1), diabetic rats were randomly assigned to either groups II, III or IV. Group II received no treatment. In Group III, phlorizin $(0.4 \mathrm{mg} \cdot \mathrm{kg}$ body weight ${ }^{-1}$. day ${ }^{-1}$ made up in a $20 \%$ solution of propylene-gly$\mathrm{col}$ ) was administered as a continuous subcutaneous infusion via an implantable mini-pump (Alzet osmotic mini-pump, Model 2ML1, Alsa Corp., Palo Alto, Calif., USA) to ensure 24 h inhibition of renal tubular reabsorption of glucose. Group IV was treated with small amounts of insulin ( $0.7 \mathrm{IU} / \mathrm{day})$ also delivered subcutaneously by an osmotic minipump. The two respective treatments were maintained for 7 days. The experimental period was therefore the same for all animals (untreated control and treated diabetic rats). During this period, tail vein blood was collected under basal and fed-state conditions every other day for the determination of plasma insulin and glucose levels and the data for which are presented in Table 1.

\section{Insulin clamp study}

Ten to twelve hours before the clamp studies food was removed from animals and, in the treated diabetic rats, insulin and phlorizin treatments were discontinued. After intraperitoneal anaesthesia with phenobarbital $\left(50 \mathrm{mg} \cdot \mathrm{kg}\right.$ body weight ${ }^{-1}$ ), two indwelling catheters were inserted into the right jugular vein for test substance infusion as previously described in detail [10]. A third catheter was inserted in the right carotid artery for blood sampling. Tracheotomy was per-
I vs II, $p<0.01$; I vs III and IV, $p<0.05$.

Fasting insulinaemia: I vs II and III, NS; I vs IV, $p<0.05$; Fed insulinaemia: I vs II and III, $p<0.05$; I vs IV, NS

formed to avoid respiratory problems. Body temperature of anaesthetized animals was maintained at $36.5-37.5^{\circ} \mathrm{C}$ using a heating blanket with a rectal probe. A 30 -min equilibration period was allowed before starting the insulin clamp studies. A primed-continuous insulin infusion ( $3 \mathrm{mU} / \mathrm{min}$ ) was then begun and maintained for 120 min. Blood was sampled, $30 \mu 1$ per sample, at 5 -min intervals and immediately centrifuged for determination of plasma glucose concentrations (Beckman Glucose Analyzer 2, Fullerton, Calif., USA). An unlabelled glucose infusion ( $16 \%$ solution weight/volume) was started $1 \mathrm{~min}$ after the beginning of the insulin infusion. Glucose infusion was then adjusted based upon plasma glucose readings as previously described [9-11]. New steady-state levels of plasma glucose and insulin concentrations were attained $30-40$ min after the beginning of the clamp studies. Mean plasma insulin levels were of the order of $524 \pm 51 \mathrm{mU} / 1$, so that tissue responsiveness to the hormone could be assessed. In all the clamp studies, plasma glucose was maintained constant at euglycaemia $(\sim 5.3 \mathrm{mmol} / \mathrm{l})$ with a coefficient of variation (C. V.) of less than $5 \%$.

\section{Glucose turnover rate}

The glucose turnover rate was measured with a primed continuous infusion of $\left[\mathrm{U}^{-14} \mathrm{C}\right]$-glucose. The priming dose was $2.25 \mu \mathrm{Ci}$, and the continuous infusion was maintained at a rate of $0.15 \mu \mathrm{Ci} / \mathrm{min}$ until completion of the study. Steady-state plasma ${ }^{14} \mathrm{C}$-glucose specific activity (C. V. $<10 \%$ ) was reached after $30-40 \mathrm{~min}$. Blood samples were taken at 40,50 and 60 min after the beginning of the ${ }^{14} \mathrm{C}$-glucose infusion and analysed as described below.

Overall glucose utilization was calculated as the average rate of glucose infusion during the last $20 \mathrm{~min}$ of the insulin clamp study plus any residual endogenous glucose production. The rate of endogenous glucose production was measured by radioisotopic dilution technique $[10,12]$.

\section{2-deoxy-glucose injection and tissue sampling}

When a new steady-state was reached during the insulin clamp study, $30 \mu \mathrm{Ci}$ of 2-deoxy-1-[ $\left[{ }^{3} \mathrm{H}\right]-\mathrm{D}$-glucose $\left(\left[{ }^{3} \mathrm{H}\right] 2 \mathrm{DG}\right)$ was injected in $30 \mu \mathrm{l}$ of $0.9 \% \mathrm{NaCl}$ solution as a bolus through a jugular vein according to a method described previously in detail $[13,14]$. Blood was sampled from the arterial catheter at 1,3, 5, 10,15,20 and 30 min for determination of $\left[{ }^{3} \mathrm{H}\right] 2 \mathrm{DG}$ specific activity and plasma glucose concentrations. After completion of blood sampling, the rats were killed by cervical dislocation and the following tissues were quickly collected: the soleus, the extensor digitorum longus, the epithroclearis, the tibialis, the diaphragm, the heart, the white epididymal and the brown fat tissues, as well as the cerebral hemispheres, the gut, and the skin. Tissue samples were collected in liquid nitrogen and kept frozen at $-70^{\circ} \mathrm{C}$ until the determination of 2-deoxy-1-[3 $\left.\mathrm{H}\right]$-glucose 6-phosphate ([3H]2DGP) concentration. 


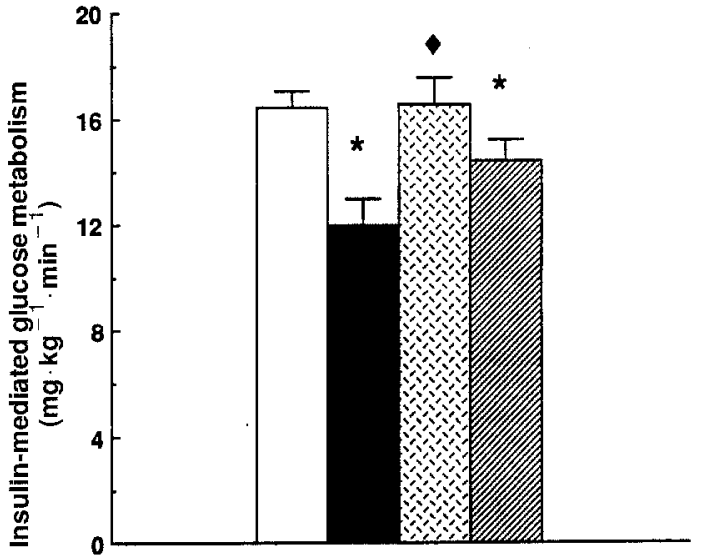

Fig. 1. Overall glucose metabolism measured during euglycaemic hyperinsulinaemic clamps in untreated lean control $(\square)$, streptozotocin (STZ)-diabetic ( $\mathbf{\square})$, STZ-diabetic phlorizin-treated (圈), or STZ-diabetic insulin-treated $(\mathbb{Z})$ rats. Insulin treatment refers to a mild treatment of the STZ-diabetic rats unable to normalize fed glycaemia. Means \pm SEM of five-six animals per group (see Table 1 ). ${ }^{*} p<0.001$ vs control rats; $\bullet p<0.01$ vs untreated diabetic rats

The glucose utilization index was derived from the amount of $\left[{ }^{3} \mathrm{H}\right] 2 \mathrm{DGP}$ measured in various tissues and was expressed as $\mathrm{ng}$. $\mathrm{mg}^{-1} \cdot \mathrm{min}^{-1}$. This technique uses accumulation of $\left[{ }^{3} \mathrm{H}\right] 2 \mathrm{DGP}$ as an indication of the glucose metabolic rate in individual tissues. $\left[{ }^{3} \mathrm{H}\right] 2 \mathrm{DPG}$, which is trapped in most tissue with the exception of the liver, is not further metabolized and can be accurately measured [1315]. From this measurement, plasma glucose levels during the clamps and the time course of $\left[{ }^{3} \mathrm{H}\right] 2 \mathrm{DG}$, a relative index of glucose utilization in different tissues can be obtained as justified previously $[14,15]$. The glucose utilization index was then calculated according to the equation described previously $[13,14]$.

\section{Analytical procedures}

Blood samples $(50 \mu \mathrm{l})$ for determination of glucose, ${ }^{14} \mathrm{C}$-glucose, and 2-deoxy-[$\left[{ }^{3} \mathrm{H}\right] \mathrm{D}$-glucose $\left(\left[{ }^{3} \mathrm{H}\right] 2 \mathrm{DG}\right)$ specific activity were deproteinized with $250 \mu \mathrm{I} \mathrm{ZnSO}{ }_{4}$ and $250 \mu \mathrm{Ba}(\mathrm{OH})_{2}$ and immediately centrifuged. An aliquot of the supernatant was used for the determination of the glucose concentration with a glucose oxidase kit (Boehringer, Mannheim, FRG). A second aliquot was counted in a liquid scintillation counter for the determination of $\left[{ }^{3} \mathrm{H}\right] 2 \mathrm{DG}$ plasma radioactivity. For determination of ${ }^{14} \mathrm{C}$-glucose turnover rate, $200 \mu \mathrm{l}$ of plasma were subjected to ion exchange resin (AG2 X8, Bio-Rad Laboratories, Richmond, Calif. USA) before counting. Blood samples $(200 \mu \mathrm{l})$ for determination of insulin were also collected and immediately centrifuged at $4^{\circ} \mathrm{C}$. Plasma was frozen at $-20^{\circ} \mathrm{C}$ for subsequent determination of insulin concentration by radioimmunoassay [16]. Determination of $\left[{ }^{3} \mathrm{H}\right] 2 \mathrm{D}$-glucose 6-phosphate was based upon its non-solubility in the Somogy reagent system. Briefly, tissue samples were incubated in stoppered plastic tubes containing $\mathrm{NaOH}(1 \mathrm{~mol} / \mathrm{l})$ at $80^{\circ} \mathrm{C}$ until complete digestion. The solution was then neutralised with $0.5 \mathrm{ml} \mathrm{HCl}(1 \mathrm{~mol} / 1)$. An aliquot of the neutralised solution was added to $1 \mathrm{ml} \mathrm{HClO}{ }_{4}(1 \mathrm{~mol} / \mathrm{l})$, while a second aliquot was added to $1 \mathrm{ml} \mathrm{ZnSO}_{4} / \mathrm{Ba}(\mathrm{OH})_{2}$ [13]. After centrifugation, supernatants were used for determination of radioactivity in a liquid scintillation counter. $\left[{ }^{3} \mathrm{H}\right] 2 \mathrm{DG}$ in the tissues was calculated as the difference between the radioactivity following $\mathrm{HClO}_{4}$ precipitation $\left(\left[{ }^{3} \mathrm{H}\right] 2 \mathrm{DG}\right.$ plus $\left.\left[{ }^{3} \mathrm{H}\right] 2 \mathrm{DG}\right)$ and the radioactivity after Somogy precipitation $\left(\left[{ }^{3} \mathrm{H}\right] 2 \mathrm{DG}\right)[13-15]$.

\section{Statistical analysis}

Values are presented as mean \pm SEM. Statistical analysis was performed by Student's $t$-test for paired and unpaired data, when appropriate.

\section{Results}

\section{Plasma insulin and glucose concentration}

After 1 week of diabetes and hyperglycaemia, untreated diabetic animals had a lower body weight than untreated control rats (controls: $227 \pm 2$, diabetics $200 \pm 1 \mathrm{~g}, n=6$; $p<0.01$ ). Compared to normal rats, whose fed glycaemia was $6.5 \pm 0.2 \mathrm{mmol} / 1$, the diabetic groups prior to treatment all had similar fed glycaemia in the $28 \mathrm{mmol} / 1$ range $(27.9 \pm 1.0 \mathrm{mmol} / 1, n=17 ; p<0.01)$. The fasting $(12 \mathrm{~h}) \mathrm{gly}-$ caemia was significantly higher in the non-treated diabetic than in normal control rats (Table 1). Glucose intolerance of STZ-treated rats was apparent when plasma glucose and insulin levels were measured. Indeed, as shown in Table 1, concomitant to hyperglycaemia, fed plasma insulin levels were lower in diabetic rats in comparison with those in control animals.

Phlorizin-treated animals had normal body weight $(232 \pm 1 \mathrm{~g})$ and exhibited a normalization of fasting plasma glucose levels and a remarkable amelioration of fed plasma glycaemia (Table 1). Phlorizin-induced amelioration of plasma glucose levels did not alter insulinaemia which remained lower than in normal control animals, both in the fasting and fed state (Table 1).

Seven days of insulin treatment with moderate amounts of subcutaneously delivered insulin was associated with normal body weight $(234 \pm 2 \mathrm{~g})$ and a slight reduction in fasting glycaemia and also fed plasma glucose levels (Table 1). The reduction in fasting plasma glucose concentration did not reach statistical significance in the fasting state and fed plasma glucose levels remained higher than those of either normal control or STZdiabetic phlorizin-treated animals (Table 1).

\section{Whole body glucose uptake and hepatic glucose production}

During euglycaemic hyperinsulinaemic clamp studies, the steady-state plasma glucose $(5.0 \pm 0.1 \mathrm{mmol} / \mathrm{l})$ and insulin $(524 \pm 51 \mathrm{mU} / \mathrm{l})$ were similar in all four groups. Under these conditions, whole body glucose uptake, shown in Figure 1, was reduced by $28 \%$ in diabetic rats (Group II) compared to control animals $(12.0 \pm 1.2$ vs $\left.16.5 \pm 0.6 \mathrm{mg} \cdot \mathrm{kg}^{-1} \cdot \mathrm{min}^{-1}, p<0.001\right)$. Phlorizin treatment of diabetic rats completely restored insulin-mediated glucose utilization to normal $\left(16.6 \pm 1.0 \mathrm{mg} \cdot \mathrm{kg}^{-1} \cdot \mathrm{min}^{-1} ; \mathrm{NS}\right.$ vs control rats; $p<0.001$ vs untreated diabetic rats). On the contrary, mild insulin treatment failed to significantly ameliorate overall glucose disposal $\left(14.5 \pm 0.9 \mathrm{mg} \cdot \mathrm{kg}^{-1}\right.$. $\mathrm{min}^{-1}$, insulin-treated vs $12.0 \pm 1.2 \mathrm{mg} \cdot \mathrm{kg}^{-1} \cdot \mathrm{min}^{-1}$, STZdiabetic rats, NS). Hepatic glucose production was completely suppressed in all four groups (data not shown). 
Table 2. Glucose utilization index $\left(\mathrm{ng} \cdot \mathrm{mg}^{-1} \cdot \mathrm{min}^{-1}\right)$ in individual tissues measured during euglycaemic hyperinsulinaemic clamps in control, diabetic, diabetic phlorizin-treated and diabetic insulin-treated rats

\begin{tabular}{|c|c|c|c|c|}
\hline Tissue & $\begin{array}{l}\text { Control } \\
\text { rats } \\
\text { (Group I) }\end{array}$ & $\begin{array}{l}\text { Diabetic } \\
\text { rats } \\
\text { (Group II) }\end{array}$ & $\begin{array}{l}\text { Diabetic } \\
\text { phlorizin- } \\
\text { treated rats } \\
\text { (Group III) }\end{array}$ & $\begin{array}{l}\text { Diabetic } \\
\text { insulin- } \\
\text { treated rats } \\
\text { (Group IV) }\end{array}$ \\
\hline Epithrochlearis & $19.2 \pm 1.7$ & $13.2 \pm 2.0^{\mathrm{a}}$ & $20.3 \pm 1.7$ & $8.5 \pm 2.8^{\mathrm{b}}$ \\
\hline Extensor digitorum longus & $20.2 \pm 2.2$ & $11.0 \pm 2.3^{\mathrm{a}}$ & $18.8 \pm 1.7$ & $12.7 \pm 3.9^{b}$ \\
\hline Tibialis & $23.8 \pm 3.8$ & $11.2 \pm 1.8^{\mathrm{a}}$ & $20.3 \pm 3.4$ & $13.1 \pm 4.4^{b}$ \\
\hline White adipose tissue & $4.0 \pm 0.7$ & $3.5 \pm 1.0$ & $2.7 \pm 0.2$ & $4.5 \pm 1.8$ \\
\hline Brown adipose tissue & $178.0 \pm 2.8$ & $98.9 \pm 21.2^{\mathrm{a}}$ & $157.2 \pm 18.0$ & $148.0 \pm 28.6$ \\
\hline Skin & $13.1 \pm 2.0$ & $6.4 \pm 0.9^{\mathrm{a}}$ & $10.0 \pm 0.8$ & $7.7 \pm 1.0^{\mathrm{b}}$ \\
\hline Brain & $19.6 \pm 1.3$ & $16.0 \pm 1.5$ & $18.4 \pm 1.6$ & $16.0 \pm 3.4$ \\
\hline Gut & $18.8 \pm 1.6$ & $15.4 \pm 0.7$ & $16.5 \pm 1.5$ & $16.1 \pm 4.7$ \\
\hline
\end{tabular}

Diabetes was produced by streptozotocin (STZ) administration to normal rats; insulin treatment refers to a mild treatment of the STZdiabetic rats with insulin.
Group I vs II: a $p<0.05$; Group I vs III: NS; Group I vs IV: ${ }^{\mathrm{b}} p<0.05$. Glucose utilization index was measured by the labelled 2-deoxyD-glucose method as described in the Materials and methods

\section{Glucose utilization index in individual tissues}

The results of glucose utilization index by individual tissues in response to the euglycaemic hyperinsulinaemic clamp are shown in Table 2. Glucose utilization index in the soleus, the epithroclearis, the extensor digitorum longus, the heart, the brown adipose tissue and the skin of diabetic rats (Group II) was reduced by $32-54 \%$ when compared to normal control rats. No significant change occurred in the white adipose tissue, brain and gut tissues (Table 2). Normalization of plasma glucose concentration with phlorizin (Group III) was associated with a restoration to normal of the tissue glucose utilization index of all muscle types studied, of brown adipose tissue, and skin. The mild insulin treatment (Group IV) that failed to significantly improve whole-body glucose disposal, also failed to normalize the glucose utilization index of most of the tissues examined.

\section{Discussion}

The present study was designed to investigate the contribution of individual tissues to the insulin resistance found in STZ-diabetic rats. The effect of the correction of hyperglycaemia or hypoinsulinaemia on insulin responsiveness was also evaluated. The present data show that: 1) 14 days of hyperglycaemia produced by prior STZ administration was followed by an approximately $30 \%$ reduction in overall insulin-mediated glucose disposal in vivo; 2) impairment in glucose utilization was seen in parallel with a reduction in the glucose uptake at the level of five skeletal muscle types, as well as at that of the heart, brown adipose tissue, and skin while no alteration occurred in the glucose utilization index of non-insulin-dependent tissues (brain and gut);3) correction of hyperglycaemia by phlorizin restored the insulin responsiveness of the above-mentioned individual tissues to normal, while moderate insulin treatment, not adequately correcting hyperglycaemia, largely failed to do so.
In the STZ-diabetic rats, the overall reduction of glucose disposal was similar to that reported by others both in awake [7-9] and anaesthetised diabetic rats [17]. Pentobarbital may reduce insulin-mediated glucose utilization $[18,19]$, but it is unlikely to qualitatively affect the present comparative data. The major reduction in the glucose utilization index of almost all the diabetic muscles examined and its restoration to normal by phlorizin treatment supports this interpretation.

Conflicting results on insulin-mediated glucose uptake by muscle of diabetic animals have been previously reported. Glucose uptake in isolated muscle from diabetic rodents has been found to be reduced [20] or normal [21, 22]. On the contrary, the present in vivo results show that all the muscles tested are resistant to the maximal effect of insulin, a result which is analogous to a finding in the soleus muscle of diabetic mice studied in vitro $[23,24]$.

It is noteworthy that the insulin resistance was equally distributed in muscle with different fibre composition (i. e. slow-oxidative vs fast-glycolytic fibres), suggesting that an early alteration in the pathway of glucose metabolism (i.e. transport or phosphorylation) may occur in diabetic animals.

Although isolated adipocytes have shown that the adipose tissue is a uniquely insulin-dependent tissue [25], the present experimental approach failed to detect any significant reduction of glucose uptake in white adipose tissue of diabetic rats. This may be related to the fact that the dose of streptozotocin used $(35 \mathrm{mg} / \mathrm{kg}$ ) was considerably smaller than those previously employed $[2,3,24]$, hence a lesser degree of insulinopoenia. Glucose utilization in brown adipose tissue has been shown to be reduced in STZ-diabetic rats [26-28]. In contrast to white adipose tissue, brown adipose tissue appears to become extremely insulin resistant in STZ-diabetic rats. This is of interest, as it links insulin responsiveness, glucose utilization and thermogenesis to diabetes mellitus [29]. Even the skin tissue contributes to the insulin resistance of the diabetic state. Although the role of the skin remains to be clarified, it is of note that glucose transporter 1 isoform is expressed 
at very high levels in cultured epithelia [30]. Streptozotocin-diabetes does not affect glucose uptake in the brain and the gut, as expected. In the presence of the plasma insulin concentration attained in the present study, hepatic glucose production was completely suppressed in all groups of rats, in agreement with previous results from our laboratory showing that the liver of anaesthetized rats is completely inhibited at plasma insulin concentrations that exceed $300 \mathrm{mU} / 1$ [10, 31]. As insulin exerts its inhibitory effect on the liver at much lower (physiologic) plasma insulin levels, the present study does not allow any investigation on the possible differentiated effects of hypoinsulinaemia and/or hyperglycaemia on the liver insulin resistance.

The present data support the hypothesis that the impairment of insulin action is an acquired feature that follows hypoinsulinaemia and/or hyperglycaemia. It has been reported previously that normalization of hyperglycaemia of diabetic rats with phlorizin can restore overall insulin-mediated glucose disposal to normal, an improvement unrelated to an amelioration in insulin output $[7,32]$.

The present data extends that of previous studies [6-8, 32] by investigating not only overall glucose handling but, more importantly, the in vivo glucose utilization index by individual tissues. It suggests that hyperglycaemia exerts a "toxic" effect mainly on insulin-dependent tissues, on several muscles, in particular. More generally, phlorizin treatment of STZ-diabetic rats is associated with an average $70 \%$ increase in glucose uptake in muscle tissues, $150 \%$ in the heart, $59 \%$ in brown adipose tissue, and $56 \%$ in the skin.

Hypoinsulinaemia induced in experimental animals is followed by an insulin-resistant state $[4,5]$. Correction of hypoinsulinaemia would therefore be expected to return insulin responsiveness to normal. By using osmotic minipumps which infused small amounts of insulin into diabetic rats, plasma levels of the hormone were increased to basal fed plasma insulin levels that were similar to those of control rats (about $65 \mathrm{mU} / \mathrm{l}$ ). However, the remaining degree of hyperglycaemia was considerably greater than that observed with the phlorizin treatment. In these animals, the overall glucose uptake was somewhat increased, an amelioration that failed to reach statistical significance. Importantly, the individual tissue glucose utilization index of this group remained lower than normal and, when improved, was lower than that seen in the STZ-diabetic animals treated with phlorizin. In the moderately insulintreated diabetic rats, the salient feature was that plasma glucose levels remained higher than that of diabetic animals treated with phlorizin. It can thus be argued that glucose "toxicity" may have been operative in the face of normal or even higher basal plasma insulin levels, thereby preventing a return of the insulin action to normal.

The applicability of the present model for quantifying the acquired degree of insulin resistance in Type 2 diabetes remains questionable. However, our data may help in understanding the amelioration of insulin sensitivity of patients with Type 1 diabetes who probably do not have hereditary insulin resistance. In a previous study, a group of Type 1 diabetic patients was treated with continuous subcutaneous insulin infusion for 6 months [33].
This intensive insulin treatment corrected hypoinsulinaemia, but failed to completely normalize the fasting plasma glucose concentration, and $\mathrm{HbA}_{1 \mathrm{c}}$ values. This was associated with an improvement, but not a normalization of insulin-mediated glucose disposal [33]. Other authors have reached similar conclusions $[34,35]$.

In conclusion, the present study shows that in streptozotocin-induced diabetes in rats, the insulin resistance results from an alteration in the glucose utilization index that occurs mostly, although not exclusively, in insulin-dependent tissues. Hyperglycaemia has a major effect and its correction appears to be critical in allowing complete recovery of insulin action. We have evaluated the effect of supraphysiologic plasma insulin concentration on insulin action at the level of several individual tissues. Therefore, the response to more physiologic plasma insulin concentrations under hypoinsulinaemic and/or hyperglycaemic conditions remains to be investigated. If the results hold true also in the physiologic range of plasma insulin levels, our observations would acquire relevant clinical implications, as they suggest that strict glycaemic control must be the goal of insulin treatment in order to restore insulin action on peripheral tissues.

Acknowledgements. Dr. G. Lisato was a recipient of a "Altri Interventi" grant from Consiglio Nazionale delle Ricerche, Italy. This work was supported by grant 32.26405 .89 from the Swiss National Science Foundation (Berne), Switzerland and by a grant-in-aid from Nestlé S. A. (Vevey), Switzerland. We acknowledge the skilful technical help of Ms. P. Arboit and Ms. I. Gerber. The excellent secretarial work of Ms. F.Touabi and Ms. T.Besson is gratefully acknowledged.

\section{References}

1. Eriksson J, Franssila-Kallunki A, Ekstrand A et al. (1989) Early metabolic defect in persons at increased risk for non-insulin-dependent diabetes mellitus. N Engl J Med 321: 337-343

2. Levy J, Gavin JR III, Fausto A, Gingerich RL, Avioli LV (1984) Impaired insulin action in rats with non-insulin dependent diabetes. Diabetes 33: 901-906

3. Dall'Aglio E, Chang H, Hollenbeck CB, Mondon CE, Sims C, Reaven GM (1985) In vivo and in vitro resistance to maximal insulin-stimulated glucose disposal in insulin deficiency. Am J Physiol 249: E312-E316

4. Reaven GM, Sageman WS, Swenson RS (1977) Development of insulin resistance in normal dogs following alloxan-induced insulin deficiency. Diabetologia 13: 459-462

5. Bevilacqua S, Barrett EJ, Smith D et al. (1985) Hepatic and peripheral insulin resistance following streptozotocin-induced insulin deficiency in dog. Metabolism 34: 817-825

6. Unger RH, Grundy S (1985) Hyperglycemia as an inducer as well as a consequence of impaired islet cell function and insulin resistance: implication for the management of diabetes. Diabetologia 28: $119-121$

7. Rossetti L, Smith D, Shulman GI, Papachristou D, De Fronzo RA (1987) Correction of hyperglycemia with phlorizin normalizes tissue sensitivity to insulin in diabetic rats. J Clin Invest 79: $1510-1515$

8. Yki-Järvinen H, Helve E, Koivisto VA (1987) Hyperglycemia decreases glucose uptake in type 1 diabetes. Diabetes 36 : 892-896

9. Rossetti L, Laughlin MR (1989) Correction of chronic hyperglycemia with vanadate, but not phlorizin, normalizes in vivo gly- 
cogen repletion and in vitro glycogen synthase activity in diabetic skeletal muscle. J Clin Invest 84: 892-899

10. Terrettaz J, Jeanrenaud B (1983) In vivo hepatic and peripheral insulin resistance as evidenced in genetically obese (fa/fa) rats. Endocrinology 112: 1346-1351

11. Del Prato S, Ferrannini E, De Fronzo RA (1986) Evaluation of insulin sensitivity in man. In: Clarke WL, Larner J, Pohl SL (eds) Methods of diabetes research, vol.II. J. Wiley, New York, pp 3576

12. Ferrannini E, Del Prato S, De Fronzo RA (1986) Glucose kinetics. Tracer methods. In: Clarke WL, Larner J, Pohl SL (eds) Methods of diabetes research, vol.II. J.Wiley, New York, pp 107-141

13. Ferré P, Leturque A, Burnol A-F, Pénicaud P, Girard J (1985) A method to quantify glucose utilization in vivo in skeletal muscle and white adipose tissue of anaesthetized rat. Biochem $\mathbf{J} 228$ : 103-110

14. James DE, Burleigh KM, Kraegen EW (1986) In vivo glucose metabolism in individual tissues of the rat. J Biol Chem 261: 6366-6374

15. Furler SM, Jenkins AB, Kraegen EW (1988) Effect of insulin on $\left[{ }^{3} \mathrm{H}\right]$ deoxy-D-glucose pharmacokinetics in the rat. Am J Physiol 255: E806-E811

16. Herbert W, Lau KS, Gottlieb CW, Bleicher SJ (1965) Coated charcoal immunoassay of insulin. J Clin Endocrinol Metab 25: $1375-1384$

17. Blondel O, Bailbe D, Portha $B$ (1989) In vivo insulin resistance in streptozotocin-diabetic-rats. Evidence for reversal following oral vanadate treatment. Diabetologia 32: 185-190

18. Pénicaud L, Ferré P, Kande J, Leturque A, Issad T, Girard J (1987) Effect of anaesthesia on glucose production and utilization in rats. Am J Physiol 252: E365-E369

19. Clark PW, Jenkins AB, Kraegen EW (1990) Pentobarbital reduces basal liver glucose output and its insulin suppression in rats. Am J Physiol 258: E701-E707

20. Maegawa H, Kobayashi M, Watanabe $N$ et al. (1986) Effect of duration of diabetic state on insulin action in isolated rat soleus muscle. Metabolism 35: 499-504

21. Chiasson J-L, Germain L, Srivastava AK, Dupuis P (1984) Hormonal regulation of glucose transport in contracting muscle from normal and diabetic rats. Metabolism 33: 617-621

22. Le Marchand-Brustel Y, Freychet P (1979) Effect of fasting and streptozotocin diabetes on insulin binding and action in the isolated mouse soleus muscle. J Clin Invest 64: 1505-1515

23. Maegawa H, Kobayashi M, Ohgaku S (1983) Insulin binding and glucose uptake in isolated muscle in spontaneously non-obese diabetic mice. Biomed Res 4: 533-536
24. Goto Y, Kida K, Kaino Y et al. (1988) Insulin action on glucose uptake by soleus muscles of nonobese diabetic mice and streptozotocin diabetic mice. Metabolism 37:74-78

25. Wardzala LJ, Cushman SW, Salans LB (1978) Mechanism of insulin action on glucose transport in the isolated rat adipose cell. J Biol Chem 253: 8002-8005

26. Aguis L, Rolls BJ, Rowe EA, Williamson DH (1981) Increased lipogenesis in brown adipose tissue of lactating rats fed a cafeteria diet: the possible involvement of insulin in brown adipose tissue hypertrophy. FEBS Lett 123: 45-48

27. Rothwell NJ, Stock MJ (1981) A role for insulin in the dietinduced thermogenesis of cafeteria-fed rats. Metabolism 30: $673-678$

28. Seydoux J, Chinet A, Schneider-Picard G et al. (1983) Brown adipose tissue metabolism in streptozotocin-diabetic rats. Endocrinology 113: 601-610

29. Bartness TJ, Billington CJ, Levine AS, Morley JE, Brown DM, Roland NE (1986) Insulin and metabolic efficiency in rats. Effects of sucrose feeding and BAT Axotomy. Am J Physiol 251: R1109-R1117

30. Gherzi R, Melioli G, De Luca Met al. (1992) The "HePG2/erythroid/brain" type glucose transporter (Glut 1 ) is highly expressed in human epidermis. Keratinocyte differentiation affects Glut 1 levels in reconstituted epidermis. J Cell Physiol (in press)

31. Terrettaz J, Assimacopoulos-Jeannet F, Jeanrenaud B (1986) Inhibition of hepatic glucose production by insulin in vivo: contribution of glycolysis. Am J Physiol 250: E346-E351

32. Rossetti L, Giaccari A, De Fronzo RA (1990) Glucose toxicity. Diab Care 13: 610-630

33. Del Prato S, Nosadini R, Tiengo A et al. (1983) Insulin-mediated glucose disposal in type 1 diabetes: evidence for insulin resistance. J Clin Endocrinol Metab 57: 904-910

34. Simonson DC, Tamborlane WV, Sherwin RS, Smith JD, De Fronzo RA (1985) Improved insulin sensitivity in patients with type 1 diabetes mellitus after CSII. Diabetes 34 [Suppl 3]: 80-86

35. Yki-Järvinen H, Koivisto VA (1984) Continuous subcutaneous insulin infusion therapy decreases insulin resistance in type 1 diabetes. J Clin Endocrinol Metab 58: 659-666

Received: 11 June 1991

and in revised form: 15 November 1991

Dr. S. Del Prato

Cattedra di Malattie del Ricambio

Via Giustiniani, 2

I-35128 Padova

Italy 